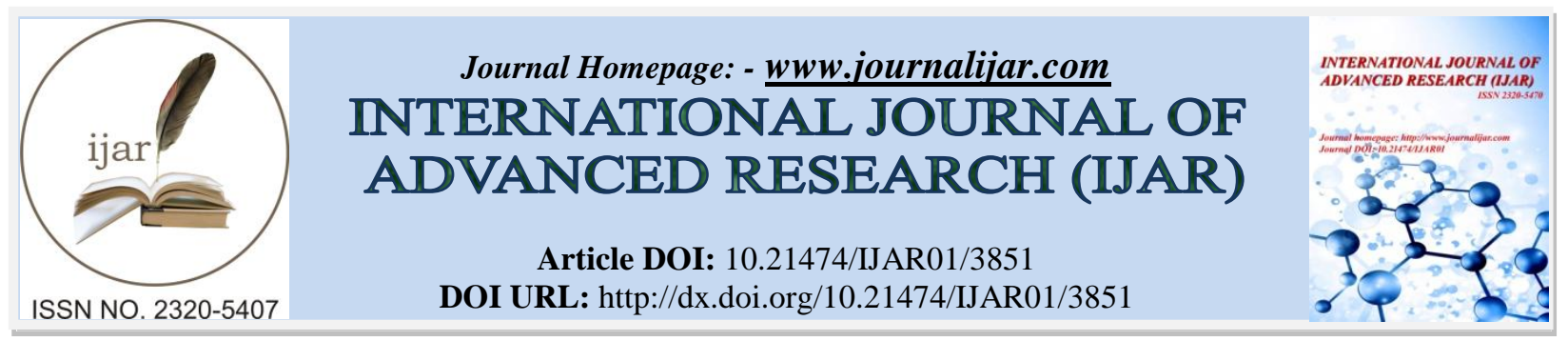

RESEARCH ARTICLE

\title{
STUDY ON THE ORIENTAL MOLE CRICKET, GRYLLOTALPA ORIENTALIS (ORTHOPTERA: GRYLLOTALPIDAE: GRYLLOTALPINAE).
}

\author{
Halimullah $^{1}$, Waheed Ali Panhwar ${ }^{1}$, Sardar Azhar Mehmood ${ }^{1}$, Shengquan Xü ${ }^{2}$, Ikram Ilahi ${ }^{3}$ and Shabir \\ Ahmed $^{1}$ \\ 1. Department of Zoology, Hazara University Mansehra Pakistan. \\ 2. College of Life Science, Institute of Zoology, Shaanxi Normal University Xi'an, 710062. \\ 3. Department of Zoology, University of Malakand Chkadara Pakistan.
}

\section{Manuscript Info}

(.........................

Manuscript History

Received: 08 February 2017

Final Accepted: 01 March 2017

Published: April 2017

Key words: -

Oriental, mole cricket, identification,

taxonomists, biodiversity

\section{Abstract}

Oriental mole cricket, Gryllotalpa orientalis Burmeister, 1838 is described from Pakistan. Morphological characters along with photographs is provided. The finding of present study aims to help with this species identification and will help future taxonomists concerned with biodiversity of this group from this region.

Copy Right, IJAR, 2017, All rights reserved.

\section{Introduction: -}

Bajour Agency is located at the exciting end of the Himalayan Range that makes variations and uncertainty in the monsoon rains from month to month and year to year. However, because of its peculiar geographical position it gets its share of rains with winter and spring rains being more predictable than rains at other times of the year. It is major agricultural sector within the FATA (Federally Administered Tribal Area) and provides an ideal situation for breeding of insects (Ali et al., 2017).

The mole crickets belong to Grylloidea group and family Gryllotalpidae with 08 genera and approximately 100 species (Cigliano et al., 2016). These insects adapted to live underground, with reduced ovipositor, fore legs vastly modified for digging and hind legs fully losing their jumping capability during the ontogenesis (Gorochov, 1995). Genus Gryllotalpa was established by Latreille in 1802 with type species Gryllus (Acheta) gryllotalpa and is characterized by having the fore tibiae with four dactyls (Chopard, 1968; Townsend, 1983; Ma \& Zhang, 2011). Nearly 100 species have been recognized including a single extinct species (Cigliano et al., 2016). Of which 26 species of Gryllotalpa mole crickets are recorded from Oriental region. 05 species i.e: Gryllotalpa orientatlis, G. hirusta, G. minuta, G. ornata and G. africana have been reported from Indian subcontinent (Chandra, 2011).

Several studies have been conducted on the mole cricket, Gryllotalpa by (Chopard, 1968; Townsend, 1983; Rongcai, 1993; Gorochov ,1995; Brandenburg et al., 2002; Kim et al., 2005; Ingrisch et al., 2006; Endo, 2006, 2007; Jin, 2008; Ma \& Zhang, 2011; Chandra et al., 2011; Park \& Lee, 2012; Cadena-Castaneda, 2015a,b) from different parts of world including Indian subcontinent. Although the Orthopteroid insect fauna of Pakistan, including the Bajour Agency have been well known, numerous faunistic and taxonomic confusion remain and most of them discourse one of the most fragmented known groups i.e: crickets. In the earlier studies, Tettigonids and Acridids received the chief attention, while the Grylloids were neglected due to their nocturnal habitat. The finding of present 
study aims to help with this species identification and will help future taxonomists concerned with biodiversity of this group from this region.

\section{Materials and Methods: -}

During field studies, adult oriental mole crickets, Gryllotalpa orientalis, were collected from different localities of Bajour Agency during the year 2016-2017 from moist ground, preferably near water basis. The easiest and effective way was the collection of specimens through mercury vapor light lamps. The collected specimens were killed and preserved in insect's cabinets. The morphological characteristics of specimens were measured or countered using a digital camera attached to a Optica SZM-SMD stereo microscope and photographed using a Nikon camera.

Identification was done by available literature. Examined specimens in this study were deposited in Insect Museum Department of Zoology, Hazara University Mansehra Pakistan.

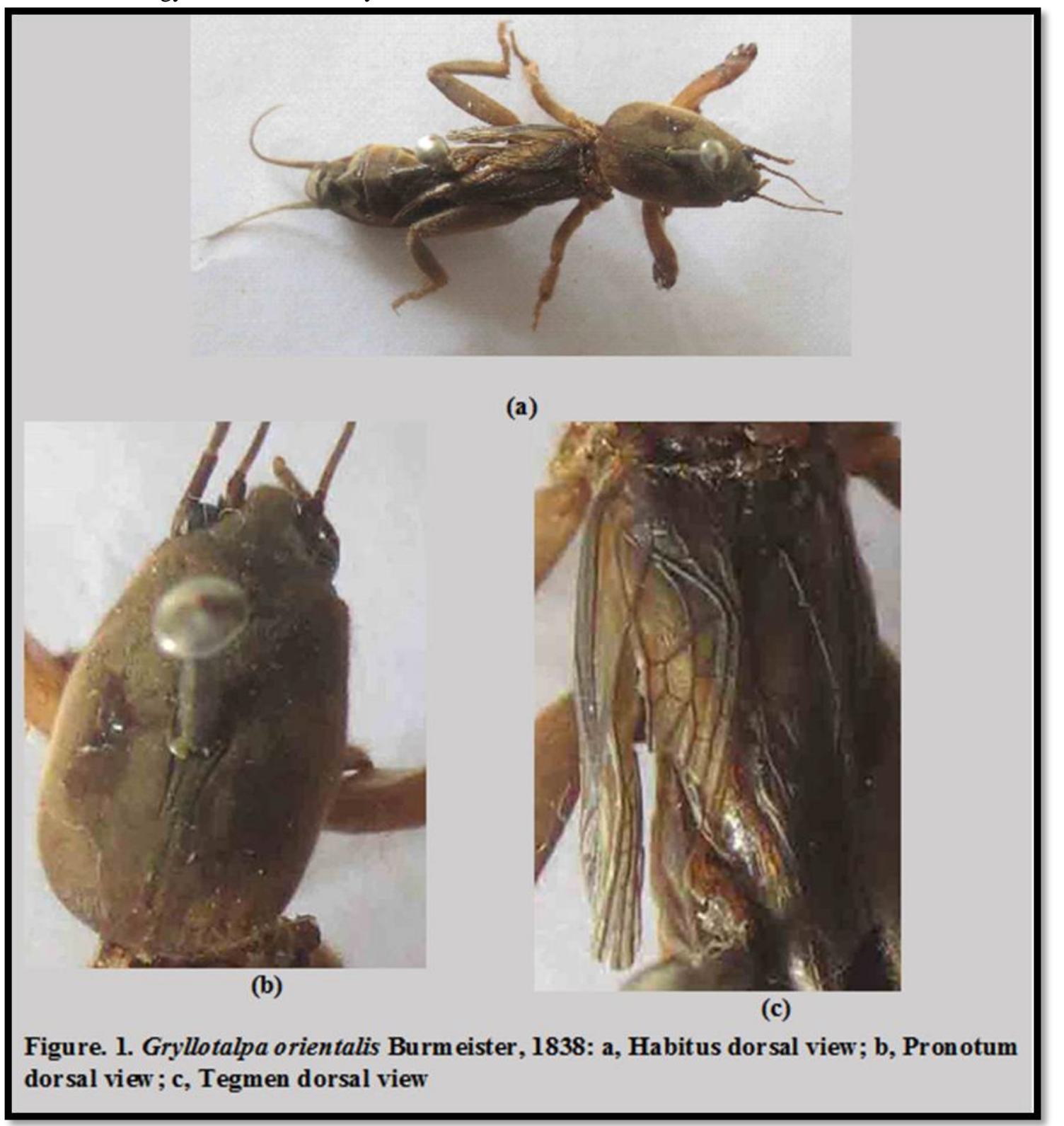




\section{Results and Discussion: -}

Taxonomy: -

Family Gryllotalpidae Leach, 1815

Subfamily Gryllotalpinae Leach, 1815

Tribe Gryllotalpini Leach, 1815

Genus Gryllotalpa Latreille, 1802

Type species: - Gryllus (Acheta) gryllotalpa Linnaeus

Diagnosis. Fore tibiae with four dactyls. Tympanum covered and opening in form of a slit. Basal spur of fore leg arising from femur. Veins in lateral field of fore wings pointing towards wing tips.

\section{Gryllotalpa orientalis Burmeister, 1838}

Figure. $1(\mathbf{a}, \mathbf{b}, \mathbf{c})$

Material examined. FATA. Bajour Agency: Village Kousar, Khar, Salarzo, Nawgai, Mammond . 18.xii.2016

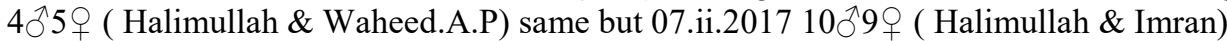

Measurement. Total Body length: 28-30, Pronotum length: 8-9, Tegmen length: 9-10

Diagnostic features.

Male. Body medium to large $28-30 \mathrm{~mm}$ slendrical in shape with yellowish-brown, paler beneath in coloration; antennae short filiform, forelegs designed for digging; pronotum large oblong 1.4 times longer than pronotal width. Ventral margin on outside of fore femur normally formed hind tibiae with three to four dorsal spurs on internal side. Tegmen shorter than the hind wings, wings usually projecting slightly from beneath of the forewings. Denticles found on stridulatory file, distributed in a series. Hind tibae with minute spines. Genitalia with sclerite, colored from yellowish brown to brown.

Female. Tegmen slightly longer than as compared to the male. Other characters same as in male.

Habitat. Gryllotalpa orientalis lives underground in moist soil, tunnelling a network of channels. Its natural habitat includes moist rich soils such as flood plains and the banks of streams and ponds as well as arable land and gardens. G.orientalis feeds on the roots of plants, tubers and rhizomes and also on insects, earthworms and other invertebrates. It comes to the surface and undertakes flight in the evenings and at night and is attracted to light sources (Endo, 2007).

Comparative note. Several confusion has been found in identification of Gryllotapa africana and G. fosser Chopard (1931) reported G.africana as widely distributed species in Africa as well as in oriental region. Later on in (1965) he concluded that G.fosser should be corrected and recognized as G. orientalis. Townsend (1983). While revising the genus synonymical G.fosser as G.africana.

Distribution. This species is widely distributed in Pakistan, India, China, Russia, Japan, Korea, South Korea, Philippines, Singapore, Indonesia, Nepal and Taiwan.

\section{Acknowledgement: -}

The authors are highly thankful to Shoaib Ali, Abdul Basit, Imran, and Rahmatullah for their help during the field survey. The first author is highly thankful to his elder brother Muhammad Ibrahim in financial help in his studies. 


\section{References: -}

1. Ali, S., Panhwar, W.A, Riffat S., Mehmood, S.A \& Wagan, M.S. (2017). First record of the genus Mermiria Stål with its species Mermiria bivittata (Serville, 1838) from Pakistan (Orthoptera, Acrididae, Gomphocerinae). Journal of Entomology and Zoology Studies .5(1): 279-281

2. Brandenburg, R. L., Xia, Y., \& Schoeman, A. S. (2002). Tunnel architectures of three species of mole crickets (Orthoptera: Gryllotalpidae). Florida Entomologist, 85(2), 383-385.

3. Cadena-Castaneda, O.J. (2015a) The phylogeny of mole crickets (Orthoptera: Gryllotalpoidea: Gryllotalpidae). Zootaxa, 3985 (4), 451-490. http://dx.doi.org/10.11646/zootaxa.3985.4.1

4. Cadena-Castañeda, O.J. (2015b) The phallic complex in Gryllotalpidae (Orthoptera: Gryllotalpoidea), and its generic implications. Zootaxa, 3981 (2), 264-274.

5. Chandra, K., Gupta, S.K., Shishodia, M.S. (2011). A Checklist of Orthoptera (Insecta) of India.EPublication, Zoological Survey of India.42.

6. Chopard, L. (1968) Family Gryllidae: Subfamilies Mogoplistinae, Myrecophilinae, Scleropterinae, Cachoplistinae, Pteroplistinae, Pentacentrinae, Phalangopsinae, Trigonidiinae, Eneopterinae; Family Oecanthidae, Gryllotalpidae. In: Beier, M. (Ed.), Orthopterorum Catalogus. Vol.12. Uitgeverij Dr. W. Junk N.V.'s, Gravenhage, pp. 215-500.

7. Chopard, L.(1931) On Grylliae from the Malay peninsula .blletin of the Raffles Museum,6, 124 -149.

8. Chopard, L(1954) Gryllides de Subma, Flores et Timor Verhandlungen der Naturforschenden Gesellshaft in Basel, 65 (1), 31-45.

9. Cigliano, M.M., Braun, H., Eades, D.C. \& Otte, D. (2016) Orthoptera Species File Online. Visited 15 September, 2016. Available from: http://Orthoptera.SpeciesFile.org (accessed 21 February 2017)

10. Endo, C. (2006). Seasonal wing dimorphism and life cycle of the mole cricket Gryllotalpa orientalis (Orthoptera: Gryllotalpidae). European Journal of Entomology, 103(4), 743-750.

11. Endo, C. (2007). The underground life of the oriental mole cricket: an analysis of burrow morphology. Journal of Zoology, 273(4), 414-420.

12. Gorochov AV (1995) System and evolution of the suborder Ensifera (Orthoptera) II. Proceedings of the Zoological Institute, Russian Academy of Sciences 260: 1-212. [In Russian]

13. Ingrisch S, Nikouei P, Hatami B (2006) A new species of mole crickets Gryllotalpa Linnaeus, 1758 from Iran (Orthoptera: Gryllotalpidae). Entomologische Zeitschrift 116(5): 195-202.

14. Jin, G. H. T. (2008). Body Surface Morphology and Wettability of the Oriental Mole Cricket (Gryllotalpa orientalis Burmeister)[J]. Transactions of the Chinese Society for Agricultural Machinery, 11, 040.

15. Kim, I., Cha, S. Y., Yoon, M. H., Hwang, J. S., Lee, S. M., Sohn, H. D., \& Jin, B. R. (2005). The complete nucleotide sequence and gene organization of the mitochondrial genome of the oriental mole cricket, Gryllotalpa orientalis (Orthoptera: Gryllotalpidae). Gene, 353(2), 155-168.

16. Ma, L. \& Zhang, Y. (2011) Redescriptions of two incompletely described species of mole cricket genus Gryllotalpa (Grylloidea; Gryllotalpidae; Gryllotalpinae) from China with description of two new species and a key to the known Chinese species. Zootaxa, 2733, 41-48.

17. Park, Y. K., \& Lee, Y. B. (2012). Studies on the Artificial Rearing of Mole Cricket, Gryllotalpa orientalis (Orthoptera: Gryllotalpidae). International Journal of Industrial Entomology, 25(2), 175-179.

18. Rongcai, Y. (1993). Study on The Occurrence of The Gryllotalpa Orientalis In Jilin And Its Prevention and Control. Journal of Jilin Agricultural Sciences, 2, 012.

19. Townsend, B.C. (1983) A revision of the Afrotropical mole-crickets (Orthoptera: Gryllotalpidae). Bulletin of the British Museum (Natural History), Entomology Series, 46 (2), 175-203 